\title{
HUBUNGAN ANTARA ENDOMETRIOSIS FERTILITY INDEX (EFI) DAN KEBERHASILAN FERTILISASI IN VITRO (FIV)
}

\author{
Adelina Amelia ${ }^{1}$, Djaswadi Dasuki², Heru Pradjatmo
}

\begin{abstract}
Background: Endometriosis is a gynecological disease that is found in $25-30 \%$ of infertile women. The most widely used staging system of endometriosis in IVF is the revised American Fertility Society ( $r$-AFS) which has limited predictive ability for pregnancy after surgery. The Endometriosis Fertility Index (EFI) is used to predict fecundity after endometriosis surgery.

Objective: To assess the relationship between EFI and the outcomes of IVF.

Methods: The study was retrospective cohort. Subjects of study were endometriosis patients who underwent IVF in Infertility Clinic of Permata Hati, Dr. Sardjito Hospital, Yogyakarta in 2012 that met inclusion and exclusion criteria. Subjects were devided into two groups: high EFI and low EFI. ROC curve was used to obtain the cut-off point. Chi-square and logistic regression statistics analysis were used.

Results and Discussion: A total of 54 cycles from 54 couples who underwent IVF were included. Cut off point for $\mathrm{EFI}$ is 6 . There is no difference in the outcomes of IVF between high and low EFI (OR 15,135; 95\% Cl 0,830-276,00; $\mathrm{p}=0,067$ ), but high EFI increased the outcome of IVF 15 times better than low EFI. The outcome of IVF was influenced by type of the embryo transfer (OR 0,126; 95\% Cl 0,028-0,566).

Conclusion: High EFI did not affect the outcomes of IVF both rated at biochemical pregnancy, clinical pregnancy and live birth. The outcomes of IVF was influenced by type of the embryo transfer. The cause of female infertility and stage of the endometriosis increased EFI score but did not affect the outcomes of IVF.
\end{abstract}

Keyword: endometriosis, infertility, endometriosis fertility index, in vitro fertilization

\begin{abstract}
ABSTRAK
Latar Belakang: Endometriosis adalah salah satu penyakit ginekologi yang ditemukan pada $25-50 \%$ wanita infertil. Sistim klasifikasi yang digunakan untuk menentukan derajat atau stadium endometriosis dalam FIV yaitu The revised American Fertility Society ( $\mathrm{r}$-AFS) yang memiliki keterbatasan dalam memprediksikan kehamilan setelah pembedahan. Endometriosis Fertility Index (EFI) adalah sistim klasifikasi endometriosis terbaru yang dapat digunakan untuk memprediksikan kehamilan setelah pembedahan.

Tujuan: Menilai hubungan antara Endometriosis Fertility Index (EFI) dan keberhasilan Fertilisasi In Vitro (FIV).

Metode: Studi kohor retrospektif. Subyek penelitian adalah pasien endometriosis yang menjalani program FIV di Klinik Permata Hati RSUP Dr. Sardjito Yogyakarta pada tahun 2012 yang memenuhi kriteria inklusi dan terlepas dari kriteria ekslusi. Subyek dibagi menjadi 2, kelompok EFI tinggi dan EFI rendah. Nilai titik potong EFI didapat dari kurva ROC. Uji statistik yang digunakan adalah Chi-square dan regresi logistik.

Hasil dan Pembahasan: Sebanyak 54 siklus dari 54 pasangan yang menjalani fertilisasi in vitro(FIV) disertakan dalam penelitian sesuai dengan kriteria inklusi dan eksklusi. Nilai titik potongditetapkan EFI=6. Tidak terdapat perbedaan secara statistik terhadap keberhasilan FIV antara EFI tinggi dan rendah (OR 15,135; IK 95\% 0,830276,00; $p=0,067$ ) tetapi secara klinis skor EFI tinggi meningkatkan keberhasilan FIV 15 kali dibanding skor EFI rendah. Keberhasilan FIV dipengaruhi oleh jenis embrio yang ditransfer (OR 7,020; IK 95\% 1,309-37,660; $p=0,023$ ). Kesimpulan: Skor EFI tinggi tidak mempengaruhi keberhasilan dalam program FIV baik dinilai pada kehamilan biokimia, kehamilan klinik, maupun kelahiran bayi hidup. Faktor yang mempengaruhi adalah jenis embrio yang ditransfer. Faktor penyebab infertilitas wanita dan stadium endometriosis meningkatkan skor EFI tetapi tidak mempengaruhi keberhasilan FIV.
\end{abstract}

\footnotetext{
1,2,3 Bagian Obstetri dan Ginekologi, Fakultas Kedokteran Universitas Gadjah Mada
} 
Kata kunci: endometriosis, infertilitas, endometriosis fertility index,fertilisasi in vitro.

\section{PENDAHULUAN}

Endometriosis adalah salah satu penyakit ginekologi yang sering terjadi pada $5-10 \%$ wanita usia reproduksi, dimana ditemukannya kelenjar endometrium fungsional dan stromanya di luar kavum uterus dan miometrium. Penderita datang dengan keluhan nyeri, infertilitas atau keduanya. Dari penelitian ditemukan bahwa hasil laparoskopi pasien dengan keluhan nyeri atau infertilitas, $20-50 \%$ disebabkan oleh endometriosis. Endometriosis bersifat kronis dan kambuhan, sehingga memerlukan manajemen jangka panjang tergantung pada keluhan yang dirasakan, dengan tujuan peningkatan kualitas hidup dan fertilitas. ${ }^{1}$

Hubungan antara endometriosis dan fertilitas masih belum jelas, walau kaitannya secara klinis telah ditemukan. Adesi/perlengketan pelvis dan perubahan anatomi pelvis oleh karena endometriosis dapat menyebabkan gangguan mekanis pada tuba falopi atau ovarium. Penyebab lainnya yang mungkin menyebabkan infertilitas adalah endometriosisassociated immunologic defect dan proses inflamasi, termasuk merusak sitokin dan makrofag cairan peritoneum. Pandangan terkini menunjukkan bahwa infertilitas pada endometriosis adalah multifaktorial, dengan banyaknya faktor yang teridentifikasi dapat mengganggu fungsi reproduksi. ${ }^{2}$

Selama ini sistim klasifikasi yang digunakan untuk menentukan derajat endometriosis atau stadium endometriosis adalahThe American Fertility Society (AFS), yang direvisi pada tahun 1985 dan 1996 menjadi klasifikasi revised-AFS ( $r$-AFS). Klasifikasi ini memiliki keterbatasan dalam memprediksi kehamilan setelah pembedahan. Sistim klasifikasi terbaru yang digunakan untuk memprediksikan kehamilan setelah pembedahan adalah
Endometriosis Fertility Index (EFI). Dalam penghitungannya, EFI menilai riwayat pasien (historical aspect) dan pada saat pembedahan dilakukan (surgical aspect), berbeda dengan AFSyang hanya menilai aspek pembedahannya saja. ${ }^{3}$

Beberapa penelitian terdahulu, menyatakan bahwa kombinasi pembedahan dan FIV menghasilkan $2 / 3$ pasien yang diteliti mengalami kehamilan dengan rata-rata waktu pembedahan dan kehamilan kurang dari 2 tahun. Kombinasi ini meningkatkan hingga 70,5\% kemungkinan kehamilan pada pasien endometriosis grade III-IV. ${ }^{4}$

EFI masih belum luas digunakan karena masih kurangnya penelitian yang dilakukan untuk membuktikan keefektifannya. Keberhasilan EFI dalam memprediksikan kehamilan spontan pada pasien endometriosis setelah dilakukan pembedahan, telah dibuktikan oleh Adamson dan Pasta. ${ }^{3}$ Ternyata EFI juga lebih akurat dalam memprediksikan keberhasilan IVF bila dibandingkan dengan klasifikasi $r$-AFS pada pasien endometriosis. ${ }^{5}$ Akan tetapi, penelitianpenelitian serupa belum banyak dilakukan. Tujuan penelitian ini adalah menilai hubungan antara Endometriosis Fertility Index (EFI) dan keberhasilan Fertilisasi In Vitro (FIV).

\section{METODE}

Rancangan penelitian adalah kohor retrospektif. Subyek penelitian adalah pasien endometriosis yang menjalani program FIV di Klinik Permata Hati RSUP Dr. Sardjito Yogyakarta pada tahun 2012 yang memenuhi kriteria inklusi dan terlepas dari kriteria ekslusi. Terdapat 54 siklus dari 54 pasangan infertil. Subyek dibagi menjadi 2, kelompok EFI tinggi dan EFI rendah. Kerahasiaan identitas subyek penelitian dijaga dan nama pasien telah diganti dengan kode 
tertentu. Kriteria inklusi adalah wanita yang terdiagnosis endometriosis berdasarkan laparoskopi di Klinik Permata Hati RSUP Dr. Sardjito Yogyakarta. Kriteria eksklusi adalah penggunaan KB hormonal, menderita penyakit keganasan, sedang menjalani terapi supresi ovarium, riwayat operasi sebelumnya, riwayat appendicitis dan peritonitis, dan riwayat menderita infeksi Chlamydia.

Hasil penelitian ini dianalisis dengan menggunakan Chi-square dan regresi logistik pada program SPSS seri 20. Nilai titik potong $E F I$ didapat dari kurva $R O C$ (Receiver Operating Characteristic) pada program Excel.

\section{HASIL DAN PEMBAHASAN}

Dalam penelitian ini didapatkan subyek penelitian sebanyak 54 wanita yang terdiagnosis endometriosis, peserta program fertilisasi in vitro (FIV), memenuhi kriteria inklusi dan terlepas dari kriteria eksklusi. Subyek penelitian tersebut dinilai dengan EFI (EFI =total skor historikal + total skor pembedahan) dan dibagi menjadi dua kelompok yakni kelompok EFI rendah sebagai kelompok kontrol dan kelompok EFI tinggi sebagai kelompok terpapar. Untuk nilai titik potong antara EFI rendah dan EFI tinggi, dilakukan pengujian diagnostik menggunakan kurva $R O C$ (Receiver Operating Characteristic) pada program Excel. Dari pengujian tersebut didapatkan nilai titik potong $\mathrm{EFI}=6$. Hasil ini sama dengan nilai titik potong EFI berdasarkan penelitian Wang et al (2013), yaitu 6. Gambar 1 dan tabel 1 menunjukkan hasil penghitungan dengan kurva ROC.

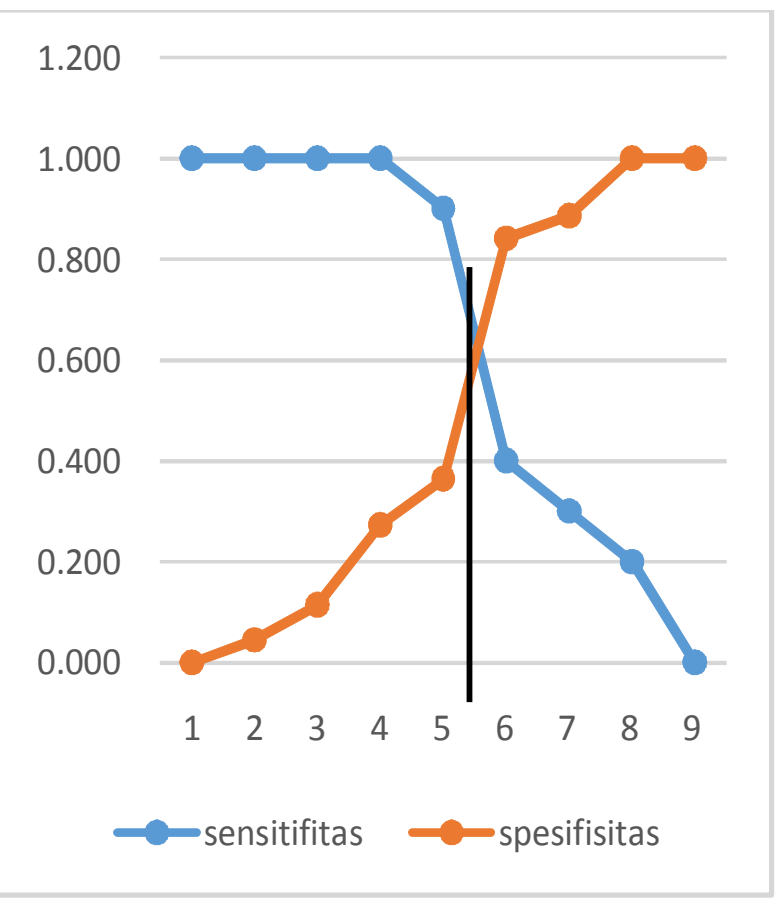

Gambar 1. Penghitungan nilai titik potong EFI menggunakan kurva ROC

Tabel 1. Tabel sensitivitas dan spesifisitas untuk penghitungan nilai titik potong EFI

\begin{tabular}{ccc}
\hline $\begin{array}{c}\text { Nilai titik } \\
\text { potong }\end{array}$ & Sensitifitas & Spesifisitas \\
\hline 1.00 & 1.000 & 0 \\
2.50 & 1.000 & 0.045 \\
3.50 & 1.000 & 0.114 \\
4.50 & 1.000 & 0.273 \\
5.50 & .900 & 0.364 \\
6.50 & .400 & 0.841 \\
7.50 & .300 & 0.886 \\
8.50 & .200 & 1 \\
10.00 & 0.000 & 1 \\
\hline
\end{tabular}

Untuk selanjutnya pembagian kelompok EFI tinggi dan rendah digunakan titik potong 6 . Menurut Wang et al, (2013), perubahan signifikan berbagai parameter luaran FIV terjadi pada $E F I=6$. Dengan menggunakan nilai titik potong $\mathrm{EFI}=6$, kelompok $\mathrm{EFI}$ 
tinggi terdapat 37 subyek, dan kelompok EFI rendah terdapat 17 subyek.

Pada penelitian ini, subyek penelitian diambil sebanyak jumlah siklus pasien yang terdiagnosis endometriosis yang melakukan laparoskopi dan menjalani program FIV di Klinik Permata Hati RSUP Dr. Sardjito pada tahun 2012.Gambaran umum subyek penelitian yang menjalani program FIV di Klinik Permata Hati (PH) pada tahun 2012 adalah sebanyak 199 subyek.Dari 199 subyek ini, 64 subyek (32\%) terdiagnosis endometriosis. Enam puluh empat subyek ini setelah diseleksi dengan kriteria inklusi dan eksklusi (3 subyek tidak melakukan laparoskopi di PH dan 7 subyek menunda transfer embrio), didapatkan 54 subyek.Dari 54 subyek penelitian, 10 subyek berhasil hamil melalui program FIV ini.

Adapun karakteristik 10 subyek yang hamil adalah sebagai berikut: 2 pasien mengalami Blighted ovum dan abortus, 1 pasien mengalami IUFD pada usia kehamilan 29 minggu, 4 pasien menjalani kehamilan tunggal hingga cukup bulan dan melahirkan bayi hidup, 2 pasien menjalani kehamilan ganda hingga cukup bulan dan melahirkan bayi hidup, dan 1 pasien menjalani kehamilan tunggal, kurang bulan dan melahirkan bayi yang kemudian meniggal pada usia 4 hari karena menderita sindrom Pierre-Robin.

Tabel 2 menunjukkan karakteristik subyek penelitian ini. Jumlah pasien dengan skor EFI $\geq 6$ yaitu 37 pasien (68,5\%). Pasien yang terdiagnosis endometriosis, terbanyak menderita endometriosis stadium II (endometriosis ringan) yaitu 22 pasien (44,4\%). Penyebab infertilitas pada subyek penelitian yang terbanyak adalah endometriosis dengan kelainan lainnya, seperti mioma, sindroma ovarium polikistik (SOPK), dan faktor tuba. Kadar hormon basal (FSH, LH, dan estrogen) dalam batas normal. Pasien-pasien ini menjalani jenis stimulasi: protokol panjang dan antagonis.
Tabel 2. Karakteristik subyek penelitian

\begin{tabular}{|c|c|c|c|}
\hline \multicolumn{2}{|c|}{ Variabel } & \multirow{2}{*}{$\frac{N}{37}$} & \multirow{2}{*}{$\begin{array}{c}\% \\
68,5\end{array}$} \\
\hline Skor EFI & $=6$ & & \\
\hline & $<6$ & 17 & 31,5 \\
\hline \multirow{2}{*}{$\begin{array}{l}\text { Jenis } \\
\text { embrio }\end{array}$} & Fresh & 41 & 75,9 \\
\hline & FET & 13 & 24,1 \\
\hline \multirow{4}{*}{$\begin{array}{l}\text { Stadium } \\
\text { endometri } \\
\text { osis }\end{array}$} & I & 13 & 24,1 \\
\hline & II & 24 & 44,4 \\
\hline & III & 13 & 24,1 \\
\hline & IV & 4 & 7,4 \\
\hline \multirow{2}{*}{$\begin{array}{l}\text { Penyebab } \\
\text { infertilitas } \\
\text { wanita }\end{array}$} & Endometriosis & 16 & 29,6 \\
\hline & $\begin{array}{l}\text { Endometriosis } \\
\text { dan kelainan } \\
\text { lainnya }\end{array}$ & 38 & 70,4 \\
\hline \multicolumn{4}{|c|}{ Kadar hormon basal } \\
\hline \multirow[t]{3}{*}{$\begin{array}{l}\text { FSH } \\
(\mathrm{mlU} / \mathrm{ml})\end{array}$} & \multicolumn{3}{|c|}{$7,87(2,11-37,73)$} \\
\hline & $<7,5$ & 34 & 63 \\
\hline & $=7,5$ & 20 & 37 \\
\hline \multirow[t]{3}{*}{$\begin{array}{l}\text { LH } \\
(\mathrm{mlU} / \mathrm{ml})\end{array}$} & \multicolumn{3}{|c|}{$4,14(0,24-16,53)$} \\
\hline & $<4$ & 31 & 57,4 \\
\hline & $=4$ & 23 & 42,6 \\
\hline \multirow[t]{3}{*}{$\begin{array}{l}\text { Estrogen } \\
\text { (pg/ml) }\end{array}$} & & $8(4$, & $193,40)$ \\
\hline & $<50$ & 44 & 81,5 \\
\hline & $=50$ & 10 & 18,5 \\
\hline \multirow[t]{4}{*}{$\begin{array}{l}\text { Protokol } \\
\text { stimulasi } \\
\text { ovarium }\end{array}$} & $\begin{array}{l}\text { Protokol } \\
\text { panjang }\end{array}$ & 23 & 42,6 \\
\hline & $\begin{array}{l}\text { Protokol } \\
\text { pendek }\end{array}$ & 0 & 0 \\
\hline & Antagonis & 31 & 57,4 \\
\hline & GnRH adepo & 0 & 0 \\
\hline
\end{tabular}


Tabel 3 menunjukkan hasil analisis bivariat skorEFI dan keberhasilan FIV.Pada kelompok EFI $\geq 6$, terdapat 9 pasien $(24,3 \%$ ) yang berhasil hamil, sedang $75,7 \%$ tidak hamil. Dapat dilihat bahwa EFI tinggi tidak berbeda bermakna secara statistika dibandingkan EFI rendah, dalam hal meningkatkan keberhasilan FIV (RR 4,135; IK 95\% 0,568-30,087; $p=0,144$ ), tetapi secara klinik, EFI $\geq 6$ menyebabkan kemungkinan keberhasilan FIV 4 kali lebih tinggi dibanding $E F I<6$.

Tabel 3. Hubungan antara skor EFI dan keberhasilan FIV

\begin{tabular}{cccccccccc}
\hline & & \multicolumn{9}{c}{ Keberhasilan FIV } & & & \\
\cline { 2 - 6 } & & \multicolumn{2}{c}{ Hamil } & \multicolumn{2}{c}{$\begin{array}{c}\text { Tidak } \\
\text { hamil }\end{array}$} & RR & IK 95\% & p \\
\cline { 2 - 6 } & & $\mathrm{n}$ & $\%$ & $\mathrm{n}$ & $\%$ & & & \\
\hline $\begin{array}{c}\text { Skor } \\
\text { EFI }\end{array}$ & $\geq 6$ & 9 & 24,3 & 28 & 75,7 & 4,135 & $\begin{array}{c}0,568- \\
30,087\end{array}$ & 0,144 \\
\hline & $<6$ & 1 & 5,9 & 16 & 94,1 & & & \\
\hline
\end{tabular}

Tabel 4 menunjukkan hasil analisis bivariat keberhasilan FIV dengan variabel jenis embrio, penyebab infertilitas wanita, stadium endometriosis, kadar hormon basal, dan protokol stimulasi ovarium.Dapat dilihat bahwa perbedaan bermakna ditemukan pada jenis embrio yang ditransfer (RR
0,211; IK 95\% 0,070-0,635; p=0,008). Variabel luar lainnya tidak menunjukkan perbedaan yang bermakna dalam meningkatkan keberhasilan FIV, yaitu faktor penyebab infertilitas wanita, stadium endometriosis, kadar hormon basal dan protokol stimulasi ovarium.

Tabel 4. Hubungan antara variabel jenis embrio, penyebab infertilitas wanita, stadium endometriosis, kadar hormon basal, dan protokol stimulasi ovarium dengan keberhasilan FIV

\begin{tabular}{|c|c|c|c|c|c|c|c|c|}
\hline & & \multicolumn{4}{|c|}{ Keberhasilan FIV } & \multirow{3}{*}{ RR } & \multirow{3}{*}{ IK95\% } & \multirow{3}{*}{$\mathrm{p}$} \\
\hline \multirow{2}{*}{\multicolumn{2}{|c|}{ Variabel }} & \multicolumn{2}{|c|}{ Hamil } & \multicolumn{2}{|c|}{ Tidak hamil } & & & \\
\hline & & $n$ & $\%$ & $\mathrm{n}$ & $\%$ & & & \\
\hline \multirow[t]{2}{*}{ Jenis embrio } & Fresh & 4 & 9,8 & 37 & 90,2 & 0,211 & $0,70-0,635$ & $0,008 *$ \\
\hline & Fet & 6 & 46,2 & 7 & 53,8 & & & \\
\hline \multirow{2}{*}{$\begin{array}{l}\text { Penyebab } \\
\text { infertilitas } \\
\text { wanita } \\
\end{array}$} & Endometriosis & 4 & 25 & 12 & 75 & 1,583 & $0,515-4,864$ & 0,459 \\
\hline & $\begin{array}{l}\text { Endometriosis } \\
\text { dan kelainan } \\
\text { lainnya }\end{array}$ & 6 & 15,8 & 32 & 84,2 & & & \\
\hline \multirow{2}{*}{$\begin{array}{l}\text { Stadium } \\
\text { endometriosis }\end{array}$} & Ringan & 6 & 16,2 & 31 & 83,8 & 0,689 & $0,223-2,128$ & $0, / U /$ \\
\hline & Berat & 4 & 23,5 & 13 & 76,5 & & & \\
\hline \multicolumn{9}{|c|}{ Kadar hormone basal } \\
\hline \multirow[t]{2}{*}{$\mathrm{FSH}$} & $<75$ & 7 & 20,6 & 27 & 79,4 & 1,373 & $0,399-4,717$ & 0,728 \\
\hline & $\geq 7,5$ & 3 & 15 & 17 & 85 & & & \\
\hline \multirow[t]{2}{*}{ LH } & $<4$ & 6 & 19,4 & 25 & 80,6 & 1,113 & $0,354-3,495$ & 1,000 \\
\hline & $\geq 4$ & 4 & 17,4 & 19 & 82,6 & & & \\
\hline \multirow[t]{2}{*}{ Estrogen } & $<50$ & 10 & 22,2 & 35 & 77,8 & 1,210 & $0,992-1,475$ & 0,183 \\
\hline & $\geq 50$ & 0 & 0 & 9 & 100 & & & \\
\hline \multirow{2}{*}{$\begin{array}{l}\text { Protokol } \\
\text { stimulasi } \\
\text { ovarium } \\
\end{array}$} & Protokol panjang & 7 & 30,4 & 16 & 69,6 & 3,145 & $0,910-10,871$ & $0,078 *$ \\
\hline & Antagonis & 3 & 9,7 & 28 & 90,3 & & & \\
\hline
\end{tabular}

Ket: $* \mathrm{p}<0,1$ dilakukan analisis multivariat 
Tabel 5 menggambarkan analisis bivariat antara variabel penyebab infertilitas wanita, stadium endometriosis, dan kadar hormon basal dengan skor EFI. Dapat dilihat bahwa perbedaan bermakna ditemukan pada variabel penyebab infertilitas wanita
(RR 1,619; IK 95\% 1,201-2,184; $p=0,011$ ) dan stadium endometriosis (RR 1,969; IK 95\% 1,093$3,549 ; p=0,005)$. Kadar hormon basal tidak menunjukkan perbedaan bermakna dalam hal meningkatkan keberhasilan FIV.

Tabel 5. Hubungan antara variabel penyebab infertilitas wanita, stadium endometriosis, dan kadar hormon basal dengan skor EFI

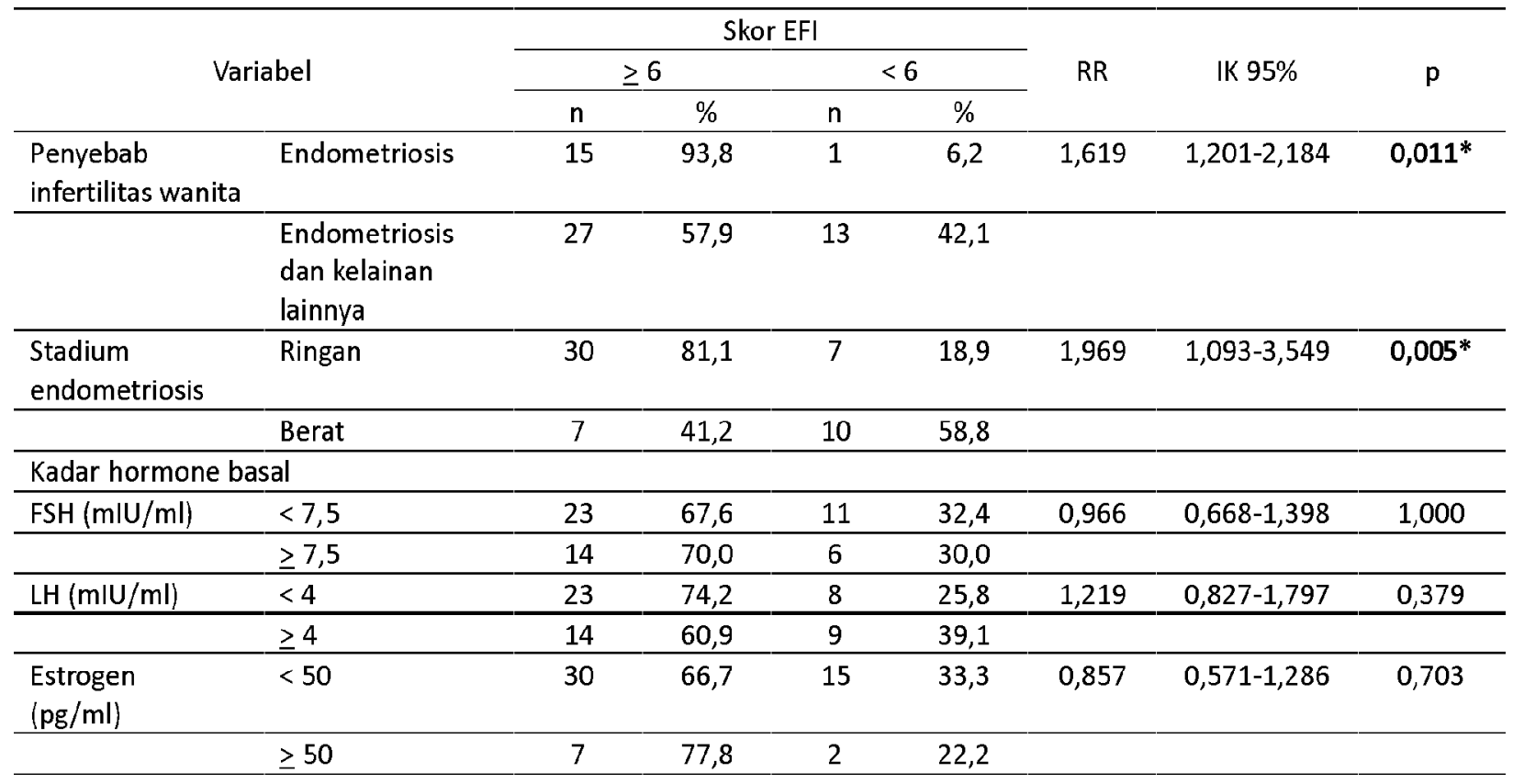

Ket: $* p<0,1$ dilakukan analisis multivariat

Hasil analisis multivariat menunjukkan bahwa variabel yang mempengaruhi keberhasilan FIV yaitu jenis embrio yang ditransfer (RO 7,020; IK 95\% 1,309-37,660; $p=0,023$ ).

Keberhasilan FIV selain dinilai dengan kehamilan secara biokimia, dimana terjadi peningkatan â-hCG $>25 \mathrm{mlU} / \mathrm{ml}$, dapat juga dinilai dengan kehamilan secara klinik dan kelahiran bayi hidup. Kehamilan secara klinik adalah kehamilan yang didiagnosis dengan USG dimana telah terbentuknya gestasional sac (GS) dan ditemukan denyut jantung janin pada hari ke 30-35 setelah embrio transfer. Kelahiran bayi hidup adalah kehamilan yang dijalani hingga cukup bulan dan melahirkan bayi hidup.
Tabel 7 dan 8 menunjukkan hasil analisis bivariat antara skor EFI dengan keberhasilan kehamilan klinik dan kelahiran hidup dari 10 subyek penelitian yang berhasil hamil melalui program FIV ini. Pada tabel tersebut, terlihat bahwa skor EFI tinggi tidak berbeda bermakna dengan skor EFI rendah baik terhadap keberhasilan kehamilan klinik (RR 1,889; IK 95\% $0,602-5,921 ; p=0,200)$ maupun terhadap keberhasilan kelahiran hidup (RR 1,326; IK 95\% $0,721-2,440 ; p=0,400$ ). Tetapi skor EFI tinggi meningkatkan kehamilan klinik 1,8 kali dibandingkan skor EFI rendah dan meningkatkan kelahiran hidup 1,3 kali dibandingkan skor EFI rendah. Penelitian Wang et al (2013), menunjukkan bahwa skor EFI tinggi meningkatkan keberhasilan kehamilan klinik, 
dan berbeda bermakna dengan skor EFI rendah $(p=0,001)$, sedang untuk keberhasilan kelahiran hidup hingga saat ini belum didapatkan data penelitian yang pernah dilakukan.

Tabel 6. Hasil analisis regresi logistik antara skor EFI dan keberhasilan FIV yang dikendalikan oleh jenis embrio, protokol stimulasi, stadium endometriosis, dan penyebab infertilitas wanita

\begin{tabular}{|c|c|c|c|c|c|}
\hline Variabel & $\begin{array}{c}\text { Model } 1 \\
\text { OR } \\
\text { IK } 95 \%\end{array}$ & $\begin{array}{c}\text { Model } 2 \\
\text { OR } \\
\text { IK 95\% }\end{array}$ & $\begin{array}{c}\text { Model } 3 \\
\text { OR } \\
\text { IK } 95 \%\end{array}$ & $\begin{array}{c}\text { Model } 4 \\
\text { OR } \\
\text { IK } 95 \%\end{array}$ & $\begin{array}{c}\text { Model } 5 \\
\text { OR } \\
\text { IK 95\% }\end{array}$ \\
\hline Skor EFI & 5,143 & 4,940 & 6,009 & 12,696 & 15,135 \\
\hline$=6$ & $0,596-44,388$ & $0,517-47,215$ & $0,588-61,396$ & $0,850-189,607$ & $0,830-276,00$ \\
\hline$>6$ & 0,136 & 0,165 & 0,130 & 0,065 & 0,067 \\
\hline Jenis Embrio & & 7,743 & 6,337 & 6,797 & 7,020 \\
\hline Fresh & & $1,642-36,508$ & $1,266-31,726$ & $1,290-35,804$ & $1,309-37,660$ \\
\hline FET & & $0,10^{*}$ & $0,025^{*}$ & $0,024^{*}$ & $0,023^{*}$ \\
\hline Protokol Simulasi & & & 3.763 & 3,424 & 3,747 \\
\hline Protokol Panjang & & & $0,722-19,608$ & $0,632-18,555$ & $0,636-22,082$ \\
\hline Antagonis & & & 0,116 & 0,153 & 0,144 \\
\hline Stadium Endometriosis & & & & 0,296 & 0,298 \\
\hline Ringan & & & & $0,043-2,036$ & $0,042-2,099$ \\
\hline Berat & & & & 0,216 & 0,244 \\
\hline Penyebab Infertilitas wanita & & & & & 0,712 \\
\hline Endometriosis & & & & & $0,112-4,538$ \\
\hline Endometriosis dan Kelainan lainnya & & & & & 0,719 \\
\hline Deviance & 48,661 & 41,641 & 39,030 & 37,480 & 37,349 \\
\hline $\mathrm{R}^{2}$ & 0,056 & 0,171 & 0,210 & 0,232 & 0,234 \\
\hline $\mathrm{N}$ & 54 & 54 & 54 & 54 & 54 \\
\hline
\end{tabular}

Tabel 7. Hubungan antara skor EFI dan keberhasilan kehamilan klinik

\begin{tabular}{lcccccccc}
\hline & & \multicolumn{3}{c}{ Keberhasilan FIV } & & & \\
\cline { 3 - 6 } & & \multicolumn{2}{c}{$\begin{array}{c}\text { Hamil UK }=6 \\
\text { Minggu }\end{array}$} & \multicolumn{2}{c}{$\begin{array}{c}\text { Hamil UK }<6 \\
\text { Minggu }\end{array}$} & RR & IK 95\% & p \\
\cline { 2 - 6 } & & $\mathrm{n}$ & $\%$ & $\mathrm{n}$ & $\%$ & & & \\
\hline $\begin{array}{l}\text { Skor } \\
\text { EFI }\end{array}$ & $\mathbf{8}$ & 8 & 88,9 & 1 & 11,1 & 1,889 & $0,602-5,921$ & 0,200 \\
& $<6$ & 0 & 0,0 & 1 & 100,0 & & & \\
\hline
\end{tabular}

Tabel 8. Hubungan antara skor EFI dan keberhasilan kelahiran hidup

\begin{tabular}{lcccccccc}
\hline & & \multicolumn{2}{c}{ Keberhasilan FIV } & & & \\
\cline { 2 - 5 } & & \multicolumn{2}{c}{$\begin{array}{c}\text { Kelahiran } \\
\text { hidup }\end{array}$} & \multicolumn{2}{c}{$\begin{array}{c}\text { Kelahiran } \\
\text { meninggal }\end{array}$} & RR & IK 95\% & p \\
\cline { 2 - 6 } & & $\mathrm{n}$ & $\%$ & $\mathrm{n}$ & $\%$ & & & \\
\hline $\begin{array}{l}\text { Skor } \\
\text { EFI }\end{array}$ & $\mathbf{6}$ & 6 & 66,7 & 3 & 33,3 & 1,326 & $0,721-2,440$ & 0,400 \\
& $<6$ & 0 & 0,0 & 1 & 100,0 & & & \\
\hline
\end{tabular}


EFI merupakan klasifikasi terbaru dari sistem penilaian endometriosis. Faktor historis dan faktor pembedahan merupakan deskripsi yang dinilai dalam klasifikasi EFI. Hasil EFI dapat untuk memprediksikan keberhasilan kehamilan dimana kehamilan didapat dengan cara alami, bukan dengan FIV. Keberhasilan EFI pada pasien endometriosis dalam memprediksikan kehamilan spontan telah berhasil diteliti oleh Adamson dan Pasta(2009), disimpulkan bahwa makin tinggi skor EFI dapat meningkatkan kejadian kehamilan spontan, dimana pasien dengan skor EFI 9-10 mengalami kehamilan sbanyak 58,4\% dalam 1 tahun. ${ }^{3}$ Empat tahun kemudian, Wang et al (2013) melakukan penelitian dan menyimpulkan bahwa EFI lebih akurat dalam memprediksikan keberhasilan FIV dibandingkan r-AFS pada pasien endometriosis. ${ }^{5}$

Dengan menggunakan kurva ROC ditemukan nilai titik potong $\mathrm{EFI}=6$, sensitifitas $=65 \%$ dan spesifisitas $=60,2 \%$, sesuai dengan penelitian Wang et al (2013) dimana ditemukan nilai titik potong EFI $=6$, sensitifitas $71,8 \%$ dan spesifisitas $=52,6 \% .{ }^{5}$ Dalam penelitian ini dari 54 pasien, yang dengan skor EFI tinggi ( $\geq 6$ ) yaitu 37 pasien $(68,5 \%)$ sedang skor EFI rendah $(<6)$ yaitu 17 pasien $(31,5 \%)$. Berbeda dengan penelitian Adamson dan Pasta (2013) dimana proporsi pasien dengan skor $\mathrm{EFI}=7$ lebih tinggi, dan angka kehamilan spontan meningkat pada skor EFI $=8-10 .^{3} \mathrm{Hal}$ ini terjadi karena pada pasien yang menjalani FIV, tidak memperhitungkan faktor tuba, seperti pada kehamilan spontan setelah operasi.

Karakteristik pasien dalam penelitian ini, umumnya mendukung keberhasilan FIV yaitu skor EFI tinggi, stadium endometriosis yang ringan (stadium I dan II), kadar hormon basal (FSH, LH, estrogen) yang dalam batas normal. Karakteristik yang tidak mendukung keberhasilan FIV yaitu jenis embrio yang ditransfer terbanyak adalah fresh embryo, penyebab infertilitas wanita bukan hanya karena endometriosis, tetapi disertai kelainan lain seperti mioma, SOPK, dan faktor tuba.

Pada kelompok EFI tinggi secara statistik tidak berbeda bermakna dibanding kelompok EFI rendah
(RR 4,135; IK 95\% 0,568-30,087; $p=0,144$ ) dalam meningkatkan keberhasilan FIV; dalam hal ini yang dinilai adalah peningkatan kadar â-hCG. Hal ini berbeda dengan hasil penelitian Wang et al (2013), dimana skor EFI tinggi $(\geq 6)$ meningkatkan prediksi keberhasilan FIV dibanding skor EFI rendah. ${ }^{5}$ Dalam penelitian ini ditemukan hasil yang berbeda dari hipotesis kemungkinan karena tidak mengeksklusi kelainan lainnya dari organ reproduksi seperti mioma uteri, SOPK, seperti pada penelitian Wang et al (2013). ${ }^{5}$ Selain itu juga, terdapat perbedaan tindakan operasi pada masing-masing pasien pada saat dilakukan laparoskopi.

Pada kelompok yang berhasil FIV didapatkan perbedaan yang bermakna pada variabel jenis embrio yng ditransfer. Dimana frozen embryo transfer(FET) meningkatkan keberhasilan FIV sebesar 0,2 kali dibanding fresh embryo. Hasil ini sesuai dengan penelitian meta analisis Roque et al (2013), dimana angka kehamilan klinis lebih tinggi pada pasien yang menerima FET dibanding fresh (RR 1,31; IK 95\% 1,101,56; $p=0,002) .{ }^{6}$ Pada penelitian Mohamed et al (2011), disimpulkan bahwa persiapan endometrium dengan $\mathrm{GnRH}$ agonis untuk FET dibandingkan dengan untuk fresh ET berhubungan dengan peningkatan angka kelahiran hidup (16,9\% dan 11,9\%) dan angka kehamilan klinis yang signifikan (18,2\% dan $12,7 \%$; p-0,048). ${ }^{7}$ Hal ini disebabkan pada FET, terjadi peningkatan reseptivitas endometrium yang telah melalui protokol hiperstimulasi ovarium terkontrol, dalam menerima FET dibanding dengan freshET.

Pada kelompok yang berhasil FIV tidak ada perbedaan yang bermakna pada faktor penyebab infertilitas wanita, stadium endometriosis, kadar hormon basal, dan protokol stimulasi ovarium. Hal ini disebabkan faktor penyebab infertilitas wanita ini telah dikendalikan terlebih dahulu sebelum menjalani FIV, yaitu dilakukan koreksi pada saat laparoskopi. Kadar hormon basal pada kedua kelompok ditemukan dalam batas normal. Protokol stimulasi ovarium pada kedua kelompok tidak memperngaruhi keberhasilan FIV. Hal ini sesuai dengan penelitian Pabucucu et al 
(2007) dimana implantasi dan angka kehamilan klinik pada pasien endometriosis stadium I dan II yang menjalani stimulasi ovarium baik dengan $\mathrm{GnRH}$ agonis maupun $\mathrm{GnRH}$ antagonis, tidak berbeda bermakna (20,5\% dan $24,2 \%)^{8}$

Pada kelompok EFI yang tinggi didapatkan perbedaan yang bermakna pada faktor penyebab infertilitas wanita dan stadium endometriosis. EFI pada penghitungannya melibatkan skor r-AFS, dimana secara detail mengobservasi dan menilai bagian, jumlah, ukuran, dan kedalaman lesi endometriosis, juga derajat adhesi yang akhirnya menghasilkan angka yang mencerminkan stadium endometriosis, sehingga mempengaruhi skor EFI. Kelainan organ reproduksi lainnya seperti mioma uteri, SOPK, dan faktor tuba meningkatkan skor EFI 1,6 kali dibanding hanya endometriosis saja pada wanita infertil, karena dengan ada kelainan ini dapat mempengaruhi fungsi tuba, fimbria, dan ovarium yang diperhitungkan dalam EFI. Pada penilaian EFI belum memperhitungkan abnormalitas uterus dan kelainan pada endometrium yang ternyata meningkatkan skor EFI dan juga mempengaruhi kejadian kehamilan pada pasien endometriosis.

Dari hasil analisis multivariat ditemukan bahwa EFI bukan merupakan variabel yang berpengaruh terhadap keberhasilan FIV, melainkan jenis embrio yang ditransfer. Hal ini berarti jenis embrio dapat menjadi prediktor keberhasilan FIV. Penelitian Mohamed et al (2011) menyimpulkan bahwa FET pada pasien endometriosis meningkatkan angka kelahiran hidup dibandingkan fresh embryo, karena terjadi sinkronisasi yang baik antara reseptivitas endometrium dan embrio yang ditransfer. ${ }^{7}$

\section{KESIMPULAN DAN SARAN}

Skor EFI tinggi pada pasien endometriosis tidak mempengaruhi keberhasilan FIV, baik dinilai dari angka kehamilan biokimia, kehamilan klinik, maupun kelahiran hidup. Faktor yang mempengaruhi adalah jenis embrio yang ditransfer.

Faktor penyebab infertilitas wanita dan stadium endometriosis meningkatkan skor EFI tetapi tidak mempengaruhi keberhasilan FIV.
EFI tinggi tidak secara langsung mempengaruhi keberhasilan FIV, tetapi pada pasien endometriosis dengan skor $\mathrm{EFI} \geq 6$ dapat disarankan untuk menjalani program FIV, diharapkan dapat memberikan hasil yang lebih optimal.

Dibutuhkan penelitian lebih lanjut dengan subyek penelitian khusus endometriosis tanpa kelainan lainnya, untuk menggambarkan keberhasilan FIV.

\section{DAFTAR PUSTAKA}

1. Leyland N. 2010. Endometriosis: Diagnosis and Management. JOGC. 32:7; Supplement 2

2. Ziegler D, Borghese B, Chapron C. 2010. Endometriosis and infertility: pathophysiology and management. Lancet. 376: 730-38

3. Adamson GD and Pasta DJ. 2009. Endometriosis fertility index: the new, validated endometriosis staging system. Fertil Steril. 09.035; p. 1-7

4. Dechanet C. 2011. Endometriosis and fertility: Results after surgery and Assisted Reproductive Technology (ART). Gyne' cologieObste' trique \& Fertilite. 39(1):37

5. Wang W, Li R, Fang T, Huang L, Ouyang N, Wang L, Zhang $Q$, Yang D. Endometriosis fertility index score maybe more accurate for predicting the outcomes of in vitro fertilisation than r-AFS classification in women with endometriosis. Reprod Biol Endocrinol. 2013 Dec 11; 11: 112. doi: 10.1186/1477-7827-11112.

6. N, Wang L, Zhang Q, Yang D. 2013. Endometriosis fertility index score maybe more accurate for predicting the outcomes of in vitro fertilization than $r$-AFS classification in women with endometriosis. Reproductive Biology and Endocrinology 11:112

7. Roque M. 2013. Fresh embryo transfer versus frozen embryo transfer in in vitro fertilization cycles: a systematic review and meta-analysis. Fertil Steril. 99:156-162

8. Mohamed AM, Chouliaras S, Jones CJ, Nardo LG. 2011. Live birth rate in fresh and frozn embryo transfer cycles in women with endometriosis. Eur J Obstet Gynecol Reprod Biol. June; 156(2): 177-80

9. Pabucucu R, Onalan G., Kaya C. 2007. GnRH agonist and antagonist protocols for stage I-II endo-metriosis and endometrioma in in vitro fertilization/ intracytoplasmic sperm injection cycles. Fertil Steril. Oct; 88(4): 832-9 